\title{
Two-way shuttle avoidance after simultaneous and staged lateral septal lesions in the rat*
}

\author{
FRANK C. KOUBA and MARY E. BUSSEY \\ University of Illinois at Urbana-Champaign \\ Champaign, Ill. 61820
}

Rats with unilateral, one-stage bilateral, and two-stage bilateral lesions, at 10-day intervals, of the lateral septal area were tested for acquisition of two-way active avoidance behavior in the shuttlebox. Performance was enhanced with one-stage bilateral lesions, but no significant enhancement was observed with unilateral or two-stage bilateral lesions. These results indicate that recovery of this aspect of septal function occurs when bilateral lesions are spaced by 10 days.

Recovery of function of various brain areas has been demonstrated with bilateral tissue removal at staged intervals (Stein, Rosen, Graziadei, Mishkin, \& Brink, 1969; Petrinovich \& Bliss, 1966), under conditions in which little recovery of function is seen when the same tissue is simultaneously removed bilaterally. Johnson (1972) and LeVere (1969) have suggested that only the phylogenetically newer portions of the brain are capable of recovery. Finger, Walbran, \& Stein (1973), on the other hand, have suggested that the appearance of recovery of function depends not only upon the structure and the interval between stage lesions, but also upon the method by which recovery is assessed. Stein et al (1969) reported recovery of function following bilateral staged lesions of the hippocampal and amygdaloid area. They assessed recovery of each area with light-dark discrimination, light-dark discrimination reversal, and passive avoidance.

The present study was designed to assess possible recovery of function following staged lesions of the lateral septal area. Bilateral lesions of this area typically facilitate two-way shuttlebox avoidance performance (Hamilton, Kelsey, \& Grossman, 1970; Schwartzbaum, Green, Beatty, \& Thompson, 1967). Hence, in contrast to most previous studies, recovery of function would be reflected in poorer performance (at the level of nonlesioned animals) and a failure of recovery in enhanced performance on the task.

\section{METHOD \\ Subjects}

The Ss were 36 naive male Sprague-Dawley rats (descendents of ARS Sprague-Dawley. Madison, Wis., stock), 105-125 days old at the start of the experiment. All animals were housed individually in plastic cages and given free access to food and water. Nine animals were assigned randomly to each of the following groups: sham operated, unilateral lesion. bilateral lesion, and staged lesion.

*This paper is sponsored by Steven F. Maier, who takes full editorial responsibility for its content. The authors thank William Greenough for his assistance. For reprints, write Mary E. Bussey, Department of Psychology, University of Illinois, Champaign, Ill. 61820. Supported by USPHS No. 5 , T01 MH 10715-07.

\section{Procedure}

Surgery was performed under sodium pentobarbital (Diabutal, $35 \mathrm{mg} / \mathrm{kg} \mathrm{IP})$ anesthesia with chloral hydrate $(160 \mathrm{mg} / \mathrm{kg} \mathrm{IP})$ as a supplemental anesthetic, if needed. To reduce respiratory distress, each $\mathrm{S}$ received atropine sulfate $(6 \mathrm{mg}$ IP) $15-20 \mathrm{~min}$ prior to anesthesia and a supplemental dose of $2.5 \mathrm{mg}$ during surgery if necessary. Coordinates for the lesioning electrode were: $1.5 \mathrm{~mm}$ anterior to bregma, $0.8 \mathrm{~mm}$ lateral to the midline suture, and $5.0 \mathrm{~mm}$ below the dura. Lesions were produced with a Stoelting 08040 Electrolytic lesion maker (anodal: $5.0 \mathrm{~mA}$ for $6.0 \mathrm{sec}$ ). Unilateral and bilateral lesions were made 6 days before testing. The second unilateral staged lesion was made after a 10-day interval, 6 days before testing. Sham-operated controls were treated identically except that the electrode was not lowered into the brain.

Testing began on the sixth day after surgery and continued for 5 consecutive days. Each session comprised 20 trials, with a 1 -min intertrial interval. Testing was carried out in a shuttlebox placed in a darkened room. The shuttlebox was $20.5 \mathrm{~cm}$ wide, $45.0 \mathrm{~cm}$ long, and $19.5 \mathrm{~cm}$ high. The grid floor was constructed of stainless steel rods $0.3 \mathrm{~cm}$ in diam placed $0.8 \mathrm{~cm}$ apart. A visual CS was presented at both ends of the shuttlebox by a 6-W $30-\mathrm{V}$ dc lamp behind a round frosted glass shield centered $16.0 \mathrm{~cm}$ above floor level. An auditory CS was presented by a Mallory Sonalert centered in the top of the shuttlebox. Shock $(0.5 \mathrm{~mA})$ was delivered to the floor grid of the appropriate side by a Grason Stadler 700 shock generator and scrambler. The visual and auditory CS preceded shock by $5 \mathrm{sec}$ and continued

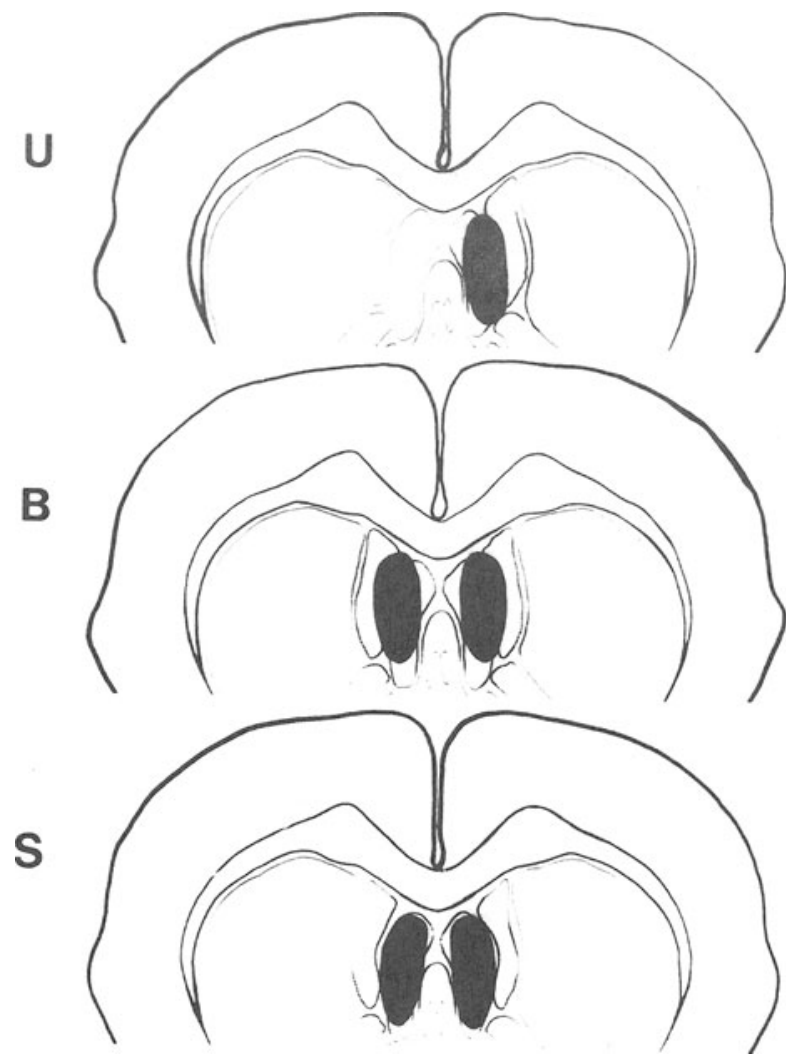

Fig. 1. Maximum (gray) and minimum (black) lesion extent for each group at $1.5 \mathrm{~mm}$ anterior to bregma. L. unilateral: B. bilateral: S. staged. (Redrawn from Skinner. 1971.) 


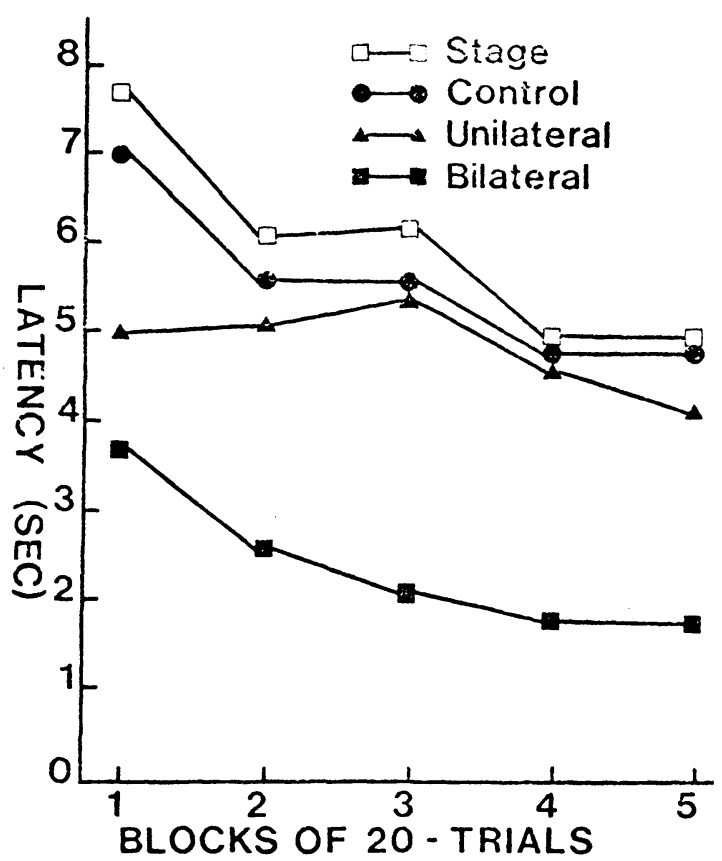

Fig. 2. Mean response latency for the four groups over blocks of 20 trials.

with the shock until a response was made. The latency required for the animal to cross the centerline of the shuttlebox, termining the trial, was recorded.

\section{RESULTS}

At the completion of behavioral testing, the animals were intercardially perfused with $10 \%$ Formalin. Frozen 75-micron sections were taken, and every third section was mounted. Sections were compared with Skinner (1971) for accuracy of the lesion(s) by superimposing the section on the atlas with a projection microscope. Seven unilateral, six bilateral, and six staged animals were found to have lesions which extended from approximately $0.25 \mathrm{~mm}$ posterior to bregma to approximately $2.00 \mathrm{~mm}$ anterior to bregma. Figure 1 shows lesion extent.

Due to death or unacceptable lesions, only 24 Ss were considered in the final analysis. The latency scores, presented in Fig. 2, were analyzed statistically with a two-factor analysis of variance ( 4 treatments by 10 trial blocks) (Winer, 1962). There was a significant difference among the four groups $(F=62.9, \mathrm{df}=3 / 240, \mathrm{p}<.01)$. The Newman-Keuls range statistic indicated that the bilateral group significantly outperformed the other three groups, while no significant difference existed among the other three groups at the .05 level (Kramer, 1956). The performance of the groups improved significantly over trials $(F=4.4, \mathrm{df}=9 / 240, \mathrm{p}<.01)$. No interaction of the group over trials was observed for the four groups in the testing period $(\mathrm{F}=1.41$, df $=$ $27 / 200, p>.10$ ).

\section{DISCUSSION}

These results confirm findings indicating that single-stage bilateral lesions enhance shuttlebox performance (Hamilton et al, 1970; Schwartzbaum et al, 1967; Krieckhaus, Simmons, Thomas, \& Kenyon, 1964) but contrast with the findings of Kenyon \& Krieckhaus (1965), which indicate that unilateral lesions also enhance shuttlebox performance.

More striking, the present results suggest that, in adult rats, two-stage destruction of approximately equal amounts of lateral septal tissue does not produce the same results as single-stage removal. In fact, the staged removal of tissue did not significantly change the Ss' performance in comparison with that of the sham-operated control or unilaterally lesioned Ss.

The apparently normal behavior of the Ss with staged bilateral lesions must be accounted for by some internal reorganization of neural mechanisms, since no training was given in the interim between lesions. Stein et al (1969) suggested that the remaining tissue must be involved in the recovery since no gross neural regeneration was observed. Nevertheless, replacement of septal projections by other fibers remains a possibility. Raisman (1969), for example, observed heterotypical reinnervation of fibers of the septal area, following lesions of the medial forebrain bundle or the fimbria, and similar sprouting may occur in areas to which the lateral septal area projects, following its destruction. However, this observation was made after a longer postoperative period and may not relate to the recovery of function observed in this experiment. Altered patterns of connectivity other than direct replacement of septal efferents may, alternatively, be involved. Though the mechanism for recovery of function is not clear, recovery of function clearly occurs in a number of limbic areas.

\section{REFERENCES}

Finger, S., Walbran, B., \& Stein, D. G. Brain damage and behavioral recovery: Serial lesion phenomena. Brain Research, 1973 , in press.

Hamilton, L., Kelsey, J., Grossman, S. Variations in behavioral inhibitions following different septal lesions in rats. Journal of Comparative \& Physiological Psychology, 1970, 70, 79-86.

Johnson, D. A. Developmental aspects of recovery of function following septal lesions in the infant rat. Journal of Comparative \& Physiological Psychology, 1972, 78, 331-348.

Kenyon, J., \& Krieckhaus, E. Enhanced avoidance behavior following septal lesions in the rat as a function of lesion size and spontaneous activity. Journal of Comparative \& Physiological Psychology, 1965, 59, 466-469.

Kramer, C. Y. Extension of multiple range tests to group means with unequal numbers of replications. Biometrices, 1956, 12 , 307-310.

Krieckhaus, E., Simmons, H., Thomas, G., \& Kenyon, J. Septal lesions enhance shock avoidance behavior in the rat. Experimental Neurology, 1964, 9, 106-113.

LeVere, T. E. Recovery of function after brainstem lesion in the rat. Journal of Comparative \& Physiological Psychology, $1969,69,339-344$.

Petrinovich, L., \& Bliss, C. Retention of a learned brightness discrimination following ablations of the occipital cortex in the rat. Journal of Comparative \& Physiological Psychology, $1966,61,136-138$.

Raisman, G. Neuronal plasticity in the septal nuclei of the adult rat. Brain Research, 1969, 14, 25-48.

Schwartzbaum, J., Green, R., Beatty, W., \& Thompson, J. Acquisition of avoidance behavior following septal lesions in the rat. Journal of Comparative \& Physiological Psychology, $1967,63,95-104$.

Skinner, J. E. Neuroscience: A laboratory manual. Philadelphia: Saunders, 1971.

Stein, D. G., Rosen, J. J., Graziadei, J., Mishkin, D., \& Brink, J. J. Central nervous system: Recovery of function. Scinece, $1969,166,528-530$.

Winer, B. J. Statistical principles in experimental design. New York: McGraw-Hill, 1962.

(Received for publication May 11, 1973.) 